\title{
Creativity and Intelligence in Children With and Without Developmental Dyslexia ${ }^{1}$
}

\author{
Rauni Jandé Roama Alves ${ }^{2}$ \\ Pontifícia Universidade Católica de \\ Campinas, Campinas-SP, Brazil
}

\author{
Tatiana de Cássia Nakano \\ Pontifícia Universidade Católica de \\ Campinas, Campinas-SP, Brazil
}

\begin{abstract}
This study aimed to verify if the creativity of children with Developmental Dyslexia (CG; $n=13)$ differs from children without difficulties in reading and writing ( $\mathrm{NG} ; n=13)$. Furthermore, we sought to verify how creativity could be related to intelligence. The Raven Colored Progressive Matrices Test and the Child Figural Creativity Test were applied in both groups. High correlations were found between intelligence and creativity in both groups, and variable correlations for the same type of analysis were found in the literature. There were no significant intergroup differences for creativity, although the NG had a higher overall average in creativity and the CG, the highest averages in most evaluated creative characteristics. The possible involvement of psychological/neuropsychological constructs with creativity, such as spatial processing and emotion, was discussed.
\end{abstract}

Keywords: creativity, dyslexia, intelligence

\section{Criatividade e Inteligência em Crianças com e sem Dislexia do Desenvolvimento}

\begin{abstract}
Resumo: Objetivou-se verificar se a criatividade de crianças com Dislexia do Desenvolvimento (GC; $n=13$ ) diferiria daquela apresentada por crianças sem dificuldades em leitura e escrita (GN; $n=13)$, verificando ainda o quanto esse construto poderia estar relacionado à inteligência nesse quadro. O teste Matrizes Progressivas Coloridas de Raven e o Teste de Criatividade Figural Infantil foram aplicados em ambos os grupos. Verificaram-se altas correlações entre inteligência e criatividade em ambos os grupos, e encontrada correlações variáveis para o mesmo tipo de análise na literatura. Não foram encontradas diferenças significativas para criatividade intergrupo, apesar de o GN ter apresentado maior média geral em criatividade e o GC maiores médias na maioria das características criativas avaliadas. Discutiu-se o possível envolvimento de construtos psicológicos/neuropsicológicos com a criatividade, como o de processamento visoespacial e emotividade.
\end{abstract}

Palavras-chave: criatividade, dislexia, inteligência

\section{La Creatividad y la Inteligencia en los Niños con y sin Dislexia del Desarrollo}

\begin{abstract}
Resumen: Este estudio investigó la diferencia entre creatividad de niños con Dislexia del Desarrollo (GC; $n=13)$ y niños sin dificultades de lectura y escritura $(\mathrm{GN} ; n=13)$, verificando además en que grado ese constructo podría estar relacionado a la inteligencia en ese cuadro. Fue utilizado la prueba Matrices Progresivas de Raven Coloreadas y la prueba de Creatividad Figurativo Infantil en los dos grupos. Fueron verificadas altas correlaciones entre inteligencia y creatividad en ambos grupos, pero correlaciones variables en la literatura sobre el mismo tipo de análisis. No fueron encontradas diferencias significativas entre los grupos para creatividad, aunque GN obtuvo un promedio general más alto en creatividad y CG promedios más altos en la mayoría de las características creativas evaluadas. Fue discutida la posible integración de constructos neuropsicológicos/ psicológicos con la creatividad, tales como procesamiento espacial y emoción.
\end{abstract}

Palabras clave: creatividad, dislexia, inteligencia

The learning disorders result from dysfunctions of the Central Nervous System, related to a "failure" in the process of acquiring and processing information, and have their own particular etiologies and diagnostic criteria (Heim et al., 2010). Among these, Developmental Dyslexia, this work's focus of investigation, is the most frequent disorder in relation to the other learning

\footnotetext{
1 Research resulting from the first author's master's thesis, undertaken under the supervision of the second author.

Support: National Council for Scientific and Technological Development (CNPq - Process No. 130367/2012-5).

2 Correspondence address:

Rauni Jandé Roama Alves. Departamento de Psicologia. Pontifícia Universidade Católica de Campinas. Av. John Boyd Dunlop, s/n, Jardim Ipaussurama. CEP 13060-904. Campinas-SP, Brazil. E-mail: rauniroama@gmail.com
}

disorders (approximately $4 \%$ of the population) and mainly involves impairment of skills related to reading (American Psychiatric Association [APA], 2013).

There are, currently, numerous explanatory models for dyslexia. Among those observed most in the literature, one can cite: (a) phonological deficit theory, which mainly addresses impairment in phonological processing as responsible for dyslexia (Shaywitz \& Shaywitz, 2008); (b) cerebellar theory, in which it is mainly cerebral dysfunctions which cause specific impairments in language, and consequently in reading (Nicolson \& Fawcett, 2011); and (c) the magnocellular theory, which relates visual processing, responsible for the perception of figure-ground contrast, with movements, both of which affect the phonological decoding of graphemes (Heim et al., 2010). Generally speaking, its evaluation involves complex procedures of clinical analysis 
and various instruments, preferentially to be undertaken by an interdisciplinary team (neurologist, psychiatrist, speech therapist, educator, and psychologist, among others) specialized in the area (Alves \& Nakano, in press).

Among the criteria for its identification, the principal manuals for diagnosis of health and mental disorders (APA, 2013; World Health Organization [WHO], 2008) emphasize: (a) the fairly frequent presence of late development of speech; (b) oral reading being characterized by distortions, substitutions or omissions; (c) reading aloud or silently being characterized by comprehension errors; (d) the difficulties must not be attributed to inadequate education and sensory compromise (the difficulties must exceed those which can be associated); and (e) compromise of the development of reading skills (results below that expected for the chronological age or for the intelligence measured, as much in aspects of correction as in speed and comprehension, measured by standardized tests).

Currently, in addition to impairments, aptitudes which may form part of the scenario of dyslexia are also being investigated. Authors have investigated some cases of learning disorders in which creativity was well developed, and have re-asserted some hypotheses present in the literature which are commonly linked with the scenario: probably, this development results from some cerebral conditions which accompany the scenario, such as, for example, greater functional development of the right hemisphere and of the parietal lobe (Chakravarty, 2009; J. Kim \& Ko, 2007).

Focusing specifically on this possible relationship between dyslexia and creativity, Alves and Nakano (in print) undertook a literature review on the issue, and the results indicated that there are no Brazilian works on this theme. Internationally, on the other hand, one can mention the study undertaken by Everatt, Steffert, and Smythe (1999), in which, after describing innumerable studies which investigated the relationship between creativity and dyslexia, they concluded that, generally speaking, groups of children and adolescents with dyslexia have higher performance in tests of figural creativity than children without the disorder. Studies undertaken by Çorlu, Özcan, and Korkmazlar $(2007,2009)$ also observed better creative performance in children with dyslexia. The authors compared drawings produced by a group of individuals with dyslexia with those of a group of individuals without dyslexia. The evaluation of the creative quality was undertaken by judges who were experienced in the area, who noted greater richness of detail and greater speed in producing the pictures obtained by the subjects with dyslexia, concluding, generally speaking, that these subjects had greater creativity.

A study undertaken by Tafti, Hameedy and Baghal (2009), which sought to identify the figural creativity of children with dyslexia, verified better performance in originality when compared with children without this disorder. Pachalska, Bogdanowicz, Tomaszewska, Lockiewicz, and Bogdanowicz (2009) undertook a study seeking to evaluate the effects of a program for training in creativity on individuals with dyslexia.
The results indicated, that, even in the pre-test, subjects with dyslexia had better performance in general creativity, and that after the training they continued to have better performance and made better use of it.

On the other hand, there are some studies which have not verified better performance in the group with dyslexia, which indicates a lack of consensus in the area. Tafti et al. (2009), through the use of the Torrance test for figural creativity, did not verify statistically different performance among children with dyslexia and children without learning difficulties. In the same way, in a study undertaken by Lockiewicz, Bogdanowicz, and Bogdanowicz (2013), which compared the creative performance of adults with a satisfactory academic life with that of adults with dyslexia, the results did not evidence significant differences between the groups.

A second topic which has received significant attention in the study of creativity is regarding its relationship with intelligence. Historic discussions may be verified focusing principally on whether such constructs are synonymous, differentiated or superimposed skills (Wechsler, Nunes, Schelini, Ferreira, \& Pereira, 2010). In Brazilian studies which sought to identify the relationships between both the constructs, variety may be ascertained in the findings, as there are studies which reported low correlations (Nakano \& Zaia, 2012; Wechsler et al., 2010) and moderate correlations (Barros, Primi, Miguel, Almeida, \& Oliveira, 2010; Nakano, 2012). Internationally, K. Kim (2005), after undertaking meta-analysis of 21 articles which contained 447 correlation coefficients and over 45,000 participants, contended the existence of a relationship between the two constructs which was small $(r=.17)$ but positive. Based on these results, various authors (K. Kim, 2005; Nakano \& Brito, 2013; Preckel, Holling, \& Wiese, 2006) have emphasized that this variety found in the literature is based on the observation that the value and significance of this relationship depends on the type of creativity and type of intelligence measured, as well as on the heterogeneity of the measurement systems used, the theory upon which each measurement system is based, and the type of population studied.

In the light of the above, the present study's objective was to ascertain whether the creative performance of children with Developmental Dyslexia differs from that presented by children without difficulties in reading and writing. In addition, it was sought to verify the extent to which creativity could be related to intelligence in both groups.

It is noted that the definition of creativity which the study is based upon was elaborated by Torrance (1965), in which creativity can be defined as cognitive processes "becoming sensitive to problems, deficiencies, gaps in knowledge, missing elements, disharmonies and so on; identifying the difficulty, searching for solutions, making guesses, or formulating hypotheses about the deficiencies, testing and retesting these hypotheses and possibly modifying and retesting them and finally communicating the results" (p. 8). 
This understanding permeated the construction of the test used in the present study.

The intelligence instrument used in the present study has fluid intelligence (Gf) as its theoretical basis, defined as skill related to the resolution of problems which cannot be resolved exclusively by the use of previous knowledge acquired through education. As a result, it covers mental operations of reasoning in new situations, which cannot be undertaken automatically (Angelini, Alves, Custódio, Duarte, \& Duarte, 1999).

\section{Method}

\section{Participants}

The total sample was made up of 26 children divided in two groups: Case Group (CG, composed of children diagnosed with Developmental Dyslexia; $n=13$ ) and Non-Case Group (NG, children with no complaints of school difficulties in reading and writing; $n=13$ ). The selection criteria for whom will be presented below, in the section on procedures.

In the CG, it may be observed that $61 \%$ of the sample was male $(n=8)$, aged between 9 and 11 years old $(M=10.92 ; S D=1.03)$. In the NG, on the other hand, $31 \%$ of the subjects were male $(n=4)$, aged between 10 and 11 years old $(M=10.61 ; S D=0.50)$. Using the Mann-Whitney Test, it was ascertained that there was no difference between the means of the ages $(U=60.50 ; p=.22)$. The Chi-squared test indicated that there were no intergroup differences in relation to the variable of $\left.\operatorname{sex}\left[\chi^{2}(1, N=26)=2.47 ; p=.11\right)\right]$.

In relation to school year, two major bands were observed: one from the 3 rd to 5 th years, and another from the 6 th to the 8 th (3rd to 5 th year corresponds to primary school; 6th to 8th, to junior high. Translator's note). The NG had a greater frequency in the second band $(69 \% ; n=9)$ and the CG had greater frequency in the first $(54 \% ; n=7)$. The Chi-squared test, however, indicated there to be no statistically significant intergroup differences in relation to this variable $\left.\left[\chi^{2}(1, n=26)=1.41 ; p=.23\right)\right]$. In relation to the type of school, it is observed that in the NG, only children from state schools were investigated $(100 \% ; n=13)$. In the $\mathrm{CG}$, the vast majority of the subjects also attended this type of school $(77 \% ; n=10)$. Fisher's Exact Test indicated that there were no statistically significant intergroup differences in relation to this variable $(p=.22)$.

\section{Instruments}

Questionnaire for father/mother/guardian. Made up of questions aiming to identify the principal aspects of the child's language development history, as well as neurological and sensory conditions (visual and hearing), use of psychotropic medications by the child, and, finally, the presence of diagnostic criteria for dyslexia. This was used in the NG's identification process.
Semi-structured interview with a teacher. This was made up of questions on school abilities in reading and writing, and on the diagnostic criteria for dyslexia. This was used in the NG's identification process.

School Performance Test (SPT) (Stein, 1994). This psychometric instrument offers an evaluation of the fundamental abilities for school performance. It evaluates writing (based on the child's writing of her own name and of words in isolation presented in the form of a dictation), arithmetic (oral resolution of problems, and arithmetical operations calculated on paper) and reading (recognition of words isolated from context). It presents tables of scores which should be obtained from the 2 nd to the 7 th year of basic education. Based on the gross scores, it offers classification in relation to what is expected for the school year in question (Lower, Average and Higher).

The influence of the variable of age was verified through a nonlinear regression equation (of the third and second degree) of the gross score for the subjects' chronological age. For discrimination between school years and types of school, a Multivariate Analysis of Variance (MANOVA) was undertaken; the results indicated major differences between school years according to the total score for each subtest. The analysis of internal consistency demonstrated precision values: writing with $\alpha=.958$, arithmetic with $\alpha=.836$ and reading with $\alpha=.958$.

Raven's Colored Progressive Matrices (RCPM) (Angelini et al., 1999). This test evaluates the intellectual development (nonverbal intelligence - fluid). The age range of application is from 5 to 11 years eight months old, and it is made up of three series $(\mathrm{A}, \mathrm{Ab}$, and $\mathrm{B})$ with 12 problems in each one which, summed, provide the general gross score with a maximum of 36 points. It is a standardized test based on an English version from 1956 (Raven, 1956). This test is approved by the Brazilian Federal Council of Psychology (CFP).

Through obtaining valid and accurate evidence, through the ANOVA, the influence of the variables of age, sex, education and type of school $(p \leq .001)$ was found. Through the application of the t-test, differences were also found between the state schools and private schools. The instrument was shown to be accurate, with the obtaining of the corrected coefficient, through the Spearman-Brown formula, of .92 for males, .90 for females, and .92 for the general sample.

The Child Figural Creativity Test (CFCT) (Nakano, Wechsler, \& Primi, 2011). This test of creativity has been validated and standardized, and is the only one currently approved by the CFP for the age range investigated here. It is made up of three activities; in the first, the child is requested to produce a drawing based on a poorly-defined stimulus, in the second, the child is requested to produce pictures based on 10 incomplete stimuli, and in the third activity, the child is requested to produce the highest number of pictures, based on 30 repeated stimuli, such that the instrument allows the elaboration of a total of up to 41 responses in the form of pictures. 
Based on the pictures produced, 12 creative characteristics are evaluated: (a) fluency (the number of relevant ideas offered by the subject); (b) flexibility (variety of types or categories of ideas); (c) elaboration (addition of details to the basic design); (d) originality (uncommon ideas); (e) expression of emotion (expression of feelings, both in the pictures and in their titles); (f) fantasy (presence of imaginary beings, from fairy tales or science fiction); (g) movement (clear expression of movement in the pictures or titles); (h) uncommon perspectives (persons or objects drawn from unusual angles); (i) internal perspective (internal view of objects or peoples' body parts, in the form of transparency); (j) use of context (creation of an environment for the picture); (k) extension of boundaries (extending the stimuli before finishing the drawings); and (l) expressive titles (going beyond the obvious description of the picture, making it abstract).

These characteristics are checked in each one of the pictures elaborated by the subject, considering the activity in which it occurred (for example: separate scores for flexibility in activity 1 , in activity 2 and in activity 3 ), so as to produce gross scores in each one of the characteristics, which are, later, grouped within a four factor model. Given that this is a test of creativity, there is no maximum number of possible points for some characteristics, for example, elaboration, which involves the scoring of the number of details added to the picture. On the other hand, fluency, given the fact that it involves the number of answers provided by the subject, is limited to the maximum number of stimuli present in the instrument ( 10 points in activity 2 , and 30 points in activity 3 ).

These characteristics make up four factors: Factor 1 Enrichment of Ideas: characteristics which it is composed of involve seeing the situation in a more detailed way, with addition of details and enrichment of the response, visualized in a broader and more dynamic context, and from a different viewpoint; Factor 2 - Emotion: characteristics which involve the use of resources linked to a more emotional perception, facilitating the process of discovering new ideas; Factor 3 - Creative Preparation: considered a "warming-up" factor, an opportunity for training for undertaking later activities which allow the more free use of creativity and a higher number of responses; Factor 4 - Cognitive Aspects: made up of creative characteristics which make use of cognitive resources, involving the search for different, original solutions which go beyond the established limits. These factors allow the identification of the stronger and weaker areas of the individual's creative potential. The test also makes it possible to obtain a general creative factor (based on the total performance in the test).

Investigations which collected valid and accurate evidence indicated values between .81 and .94 of correlation concurrent validity with the Torrance Test - Figural, placing emphasis on the fact that in all of the skills evaluated, levels of significance of $p \leq .001$ were found, as were rates of accuracy through testing and retesting of between .84 and $.95(p \leq .001)$. Variance Analysis (ANOVA) was undertaken, and the results indicated effects of the school year $(F=6.93, p \leq .000)$, region $(F=7.09, p \leq .000)$ and type of school $(F=11.26, p \leq .000)$.

\section{Procedure}

Data collection. The data for CG were collected in the State University of Campinas Teaching Hospital, in the Neurological Learning Difficulties Outpatient Center. In this place, the children initially undergo psychological/ neuropsychological assessment during which a battery of psychological tests is administered. In this way, the data on intelligence (the RCPM test) and creativity (CFCT) were collected in this first stage of investigation of the outpatient center by one of the authors of the present work. A mean of two 50 minutes sessions were used for administering both instruments.

After this first stage of attendance in the outpatient center, and, in particular, of investigating the school difficulties in reading and writing (also undertaken using the SPT test), the team's psychologists referred the children for interdisciplinary evaluation and the diagnoses were finalized, these including that of dyslexia.

In those cases where the diagnosis of dyslexia was confirmed, the parents/guardians were contacted and individual meetings were arranged. The study's objectives were presented in this meeting, and express authorization was requested through signing the terms of consent, in order to use the data already collected during the psychological/ neuropsychological evaluation, the children's confidentiality and anonymity being guaranteed.

In relation to the NG, on the other hand, all the data were collected in the participants' school. A school was selected which had children with characteristics similar to the majority of children of the CG; as a result, a state school was selected, on the outskirts of the same city in which the hospital was located, and which attended the age range investigated. The collection of these data followed the following sequence: (1) holding a semi-structured interview with one of the teachers (preference was given to Portuguese language teachers), in order to identify children with no difficulties in reading or writing, and who had no diagnostic criteria for dyslexia (APA, 2013), this interview lasting approximately 15 minutes; (2) the sending of a questionnaire to the parents/guardians of the children indicated by the teachers, with the aim of identifying children who had had no significant delays in initiating speech, in learning to read or write (as this characteristic is commonly presented by individuals with dyslexia) (APA, 2013), who had no history of neurological diseases (as well as children with dyslexia) (WHO, 2008), who were not using psychotropic medications, and who did not meet diagnostic criteria for dyslexia (APA, 2013).

Those cases in which all of these conditions were met were invited to participate in the study: the parents were invited to a meeting, held individually, in which the objectives 
and the procedures to be undertaken were presented, and - if they agreed with the research - their express authorization was requested through signing the terms of consent.

The next step (3) was the application of the SPT test, so as to select only those children whose performance in reading and writing was within that expected for the school year and age; (4) administration of the RCPM intelligence test; (5) administration of the CFCT. The application of all these tests in the NG was undertaken individually, and split into two sessions of approximately 50 minutes with each child.

Data analysis. The SPSS Statistics 20.0 for Windows $^{\circledR}$ (Statistical Package for Social Sciences, SPSS Inc, Chicago, IL, USA, 2008) was used for the data analysis. Descriptive statistics was used for analysis of frequency, mean, standard deviation, minimum and maximum scoring and nonparametric inferential statistics, for the intergroup comparisons (Mann-Whitney test) and correlation (Spearman correlation). So as to control for the effects of age and level of intelligence in the correlation, the Pearson Correlation parametric test was used, which allows this analysis.

\section{Ethical Considerations}

First of all, a request was made for authorization to undertake the research in the State University of Campinas Teaching Hospital where the CG was found, and in the schools, where the NG was sought. The project was submitted to the Research Ethics Committee of the Pontifícia Universidade Católica de Campinas and was approved (CAAE: 13375413.8.0000.5481), at which point the research was initiated.

\section{Results}

In Table 1, it may be observed that the NG had higher mean scores in the majority of the factors evaluated by the CFCT, as well as in the total score, except in Factor 2, in which the $\mathrm{CG}$ had a higher mean. However, when the test of differences of means was used, the results demonstrated that there were no significant intergroup differences (Factor 1: $U=77.00 ; p=.72$; Factor $2: U=77.00 ; p=.72$; Factor 3: $U=64.00 ; p=.31$; Factor $4: U=74.00 ; p=.61$; Total Score: $U=77.50 ; p=.72$ ), such that, in relation to creativity, the performance between the groups was not shown to be different.

The means obtained for each characteristic evaluated by the CFCT were also calculated. In the 31 measurements which make up the test, in the comparison of the means, no statistically significant differences were ascertained for any characteristic, in spite of the CG having presented higher means in 18 of them.

The classifications obtained by the participants from both groups (in accordance with the table provided in the instrument's manual) were analyzed for each one of the factors, and for the total creativity. The possible classifications are: higher, above average, average, below average, and lower. In the NG, most of the students obtained the result average in Factor 1 (46\%), Factor 2 (38\%), Factor $3(31 \%)$ and total creativity (31\%). The only exception occurred in

Table 1

Description and Comparison of the Groups in the Factors and Total Scores of the CFCT and in the RCPM

\begin{tabular}{|c|c|c|c|c|c|c|c|}
\hline CFCT & Groups & $M$ & $S D$ & $M d n$ & Min & Max & $p$-value ${ }^{\mathrm{a}}$ \\
\hline \multirow{3}{*}{$\begin{array}{l}\text { Factor } 1 \\
\text { Enrichment of Ideas }\end{array}$} & $\mathrm{CG}$ & 40.15 & 19.60 & 42.00 & 11 & 75 & \multirow[t]{3}{*}{.72} \\
\hline & NG & 43.00 & 15.41 & 41.00 & 24 & 75 & \\
\hline & Total & 41.58 & 17.33 & 41.50 & 11 & 75 & \\
\hline \multirow{3}{*}{$\begin{array}{l}\text { Factor } 2 \\
\text { Emotion }\end{array}$} & $\mathrm{CG}$ & 6.92 & 8.04 & 5.00 & 0 & 25 & \multirow[t]{3}{*}{.72} \\
\hline & NG & 4.08 & 4.36 & 2.00 & 0 & 12 & \\
\hline & Total & 5.50 & 6.50 & 2.50 & 0 & 25 & \\
\hline \multirow{3}{*}{$\begin{array}{l}\text { Factor } 3 \\
\text { Creative Preparation }\end{array}$} & $\mathrm{CG}$ & 4.31 & 4.11 & 3.00 & 0 & 13 & \multirow[t]{3}{*}{.31} \\
\hline & NG & 5.85 & 5.59 & 4.00 & 0 & 20 & \\
\hline & Total & 5.08 & 4.87 & 3.00 & 0 & 20 & \\
\hline \multirow{3}{*}{$\begin{array}{l}\text { Factor } 4 \\
\text { Cognitive Aspects }\end{array}$} & $\mathrm{CG}$ & 46.15 & 12.36 & 49.00 & 22 & 68 & \multirow[t]{3}{*}{.61} \\
\hline & NG & 51.15 & 16.91 & 48.00 & 21 & 83 & \\
\hline & Total & 48.65 & 14.73 & 48.50 & 21 & 83 & \\
\hline \multirow{3}{*}{$\begin{array}{l}\text { Total Score } \\
\text { CFCT }\end{array}$} & $\mathrm{CG}$ & 99.08 & 35.17 & 99.00 & 34 & 155 & \multirow[t]{3}{*}{.72} \\
\hline & NG & 104.08 & 30.15 & 100.00 & 50 & 152 & \\
\hline & Total & 101.58 & 32.19 & 99.50 & 34 & 155 & \\
\hline \multirow[t]{3}{*}{ RCPM } & $\mathrm{CG}$ & 24.46 & 5.50 & 24 & 14 & 34 & \multirow[t]{3}{*}{.057} \\
\hline & NG & 32.15 & 15.04 & 29 & 20 & 80 & \\
\hline & Total & 28.31 & 11.77 & 27 & 14 & 80 & \\
\hline
\end{tabular}

Note. $\mathrm{CG}=$ Case Group; $\mathrm{NG}=$ Non-case Group; $M=$ Mean; $S D=$ Standard Deviation; $M d n=$ Median; Min = Minimum; Max = Maximum; ${ }^{\mathrm{a}}$ Mann-Whitney. 
relation to Factor 4, in which the classifications were more balanced: average, below average and lower, all with $23 \%$. In relation to the $\mathrm{CG}$, the classification of average was obtained most in Factor 1 (38\%), Factor 4 (54\%) and total creativity (31\%). In Factor 2, the majority obtained the score of higher (46\%) and in Factor 3, lower (46\%). Fisher's Exact test did not indicate a difference between the classifications obtained in the two groups either for the four factors (Factor 1, $p=.73$; Factor $2, p=.15$; Factor $3 ; p=1.00$; Factor $4, p=.45$ ) or for the total $(p=.91)$.

In relation to the means obtained in the RCPM test, it may be ascertained in Table 1 that the NG had a higher mean $(M=32.15)$ than the CG $(M=24.46)$. However, in comparing these means, statistically significant differences were not found (Mann-Whitney; $U=47.00 ; p=.057$ ). Next, as in the test for creativity, the classifications obtained by the participants were also categorized. The possible classifications were similar to those of the CFCT. Both the $\mathrm{NG}$ and $\mathrm{CG}$ obtained higher frequencies in the classification average in the test: the $\mathrm{NG}$ with $46 \%$, and the $\mathrm{CG}$ with $54 \%$. In the NG, an important concentration of results above average occurs, with $38 \%$ of the participants situated in this classification. On the other hand, in the CG, the classifications of higher and below average, stand out, both with $23 \%$. Fisher's Exact test did not indicate a difference between the classifications obtained between the groups $(p=.09)$.

Both in the general sample $(r=.728 ; p<.001)$, in the NG $(r=.737 ; p=.004)$ and in the $\mathrm{CG}(r=.801, p=.001)$, one can

Table 2

Matrix of Correlation Between the Factors and the CFCT Total With the Total Score of the RCPM Test

\begin{tabular}{|c|c|c|c|c|c|}
\hline \multicolumn{6}{|c|}{ General Sample } \\
\hline & Rav & $\mathrm{F} 1$ & $\mathrm{~F} 2$ & $\mathrm{~F} 3$ & $\mathrm{~F} 4$ \\
\hline $\mathrm{F} 1$ & $.742^{* *}$ & - & - & - & - \\
\hline $\mathrm{F} 2$ & .343 & $.500^{* *}$ & - & - & - \\
\hline F3 & .277 & $.535^{* *}$ & .067 & - & - \\
\hline F4 & .289 & .320 & .087 & -.027 & - \\
\hline $\mathrm{TC}$ & $.728^{* *}$ & $.932^{* *}$ & $.579^{* *}$ & $.433^{*}$ & $.520^{* *}$ \\
\hline \multicolumn{6}{|c|}{ NG Group } \\
\hline F1 & $.814^{* *}$ & - & - & - & - \\
\hline F2 & .171 & .507 & - & - & - \\
\hline F3 & .378 & .511 & -.031 & - & - \\
\hline $\mathrm{F} 4$ & .385 & .424 & .165 & -.143 & - \\
\hline TC & $.737^{* *}$ & $.926^{* *}$ & .478 & .348 & $.707^{* *}$ \\
\hline \multicolumn{6}{|c|}{ CG Group } \\
\hline F1 & $.810^{* *}$ & - & - & - & - \\
\hline $\mathrm{F} 2$ & $.616^{*}$ & $.597 *$ & - & - & - \\
\hline F3 & .117 & .511 & .170 & - & - \\
\hline F4 & .076 & .225 & -.092 & -.021 & - \\
\hline $\mathrm{TC}$ & $.801^{* *}$ & $.953^{* *}$ & $.691 * *$ & .474 & .242 \\
\hline
\end{tabular}

Note. $r=$ Spearman correlation coefficient; F1 = Factor 1 of Creativity; F2 = Factor 2 of Creativity; F3 = Factor 3 of Creativity; $\mathrm{F} 4=$ Factor 4 of Creativity; TC $=$ Total CFCT; Rav $=$ Total RCPM. $* p<.05 . * * p<.01$. observe strong and significant correlations (Spearman test) between the RCPM test and the total of the CFCT (Table 2).

In undertaking correlations controlling for the variable of age (Pearson test) it was verified that in the general sample $(r=.431, p=.032)$ there was moderate and significant correlation, as in the CG $(r=.664, p=.019)$. In the NG, moderate correlation was also observed, although not significant $(r=.479 ; p=.115)$. In its turn, in order to control for the level of intelligence, analysis by levels was established, in which the percentiles of 0 to 33 were adopted as below average, from 34 to 66 as average and from 67 as above average. It was ascertained that in the general sample there was a moderate and significant correlation $(r=.554$, $p=.004)$, that in the NG there was a strong and significant correlation $(r=.710, p=.01)$ and that in the $\mathrm{CG}$, there was a weak and nonsignificant correlation $(r=.178, p=.579)$.

\section{Discussion}

The principal aim of the present study was to investigate the creativity of children with dyslexia in comparison with children without difficulties in reading and writing. In addition, it was sought to ascertain the extent to which this construct may be related to intelligence, also in both groups.

The results indicated that, generally speaking, there was similar creative performance between the two groups investigated. Similar results to the findings here, indicating the absence of difference between the groups in relation to creativity, were also found in a study undertaken by Lockiewicz et al. (2013) and Tafti et al. (2009), in which they compared the creative performance of subjects with dyslexia with that of subjects without learning difficulties - and did not ascertain differences between the groups.

Some hypotheses have been raised to explain why discrepant results have not been found between the groups; these in general involve historical variables which underlie both creativity and dyslexia. Numerous neuroscientific studies, mainly undertaken during the 1960s, 1970s and 1980s, indicated the right hemisphere of the brain as mainly responsible for creative production (Hoppe, 1988): in a more localizationalist perspective, the discussions were based on the premise that the left hemisphere specializes in logical, verbal and analytic thinking, while the right is related to more intuitive, perceptive and holistic thinking. During the same period, there were also some productions which emphasized studies of dyslexia in relation to the cerebral hemispheres, which indicated the right hemisphere as slightly greater than the left in this case (Galaburda \& Geschwind, 1980). These concomitant occurrences could explain in some way the first assertions - still found today in the literature - that due to this cerebral characteristic, subjects with dyslexia are more creative.

Currently, however, studies in neurosciences are increasingly debunking this dichotomy regarding the functioning of the hemispheres, probably due to the advent and greater popularity of functional neuroimaging tests. As an example, one can cite the studies undertaken by 
Abraham et al. (2012) and Huang et al. (2013), which sought to identify the dominance of one or other hemisphere on creativity, but found that both hemispheres were involved with this capability.

On the other hand, what could explain some of the present study's findings, such as the CG presenting higher means in Factor 2 (emotion) and the large majority of classifications of higher and above average in this same factor, as well as better performance in 18 of the 31 items which make up the CFCT? In the investigation undertaken by Lockiewicz et al. (2013), in addition to creativity, these researchers also evaluated visuospatial skills and motivation. As with creativity, better performance from the group with dyslexia in the visuospatial skills was not ascertained, although better performance in motivation tasks was verified. These authors speculate that the creative characteristics often attributed to those who have dyslexia may have a greater link with emotional factors, such as motivation, and even with personality characteristics, but not with cognitive factors. In the same way, Torrance and Safter (1999) emphasize that the emotional aspects have been considered to be elements of great importance in creativity, often even more important than cognitive factors. Such assertions could explain the results obtained in the present study and, in addition, would support investigations relating to emotional factors in dyslexia, which indicate a greater emotional sensitivity in this case (Lockiewicz et al., 2013).

Other variables which could explain this better performance of the CG may be found in some neuropsychological findings and assumptions. Eide and Eide (2011) describe dyslexia not only as a disorder, but as a neurobiological condition which provides a different pattern of brain organization which promotes specific difficulties and abilities, these last being related to visuospatial processing.

In neuropsychology there is held to be a link between figural creativity and these visuospatial skills (West, 2009). However, impairment of these abilities in subjects with dyslexia is commonly found in the literature (Facoetti, Paganoni, Turatto, Marzola, \& Mascetti, 2000), but some nuances must and are being investigated, mainly in investigations which have greater ecological validity. For example, in studies undertaken by Brunswick, Martin and Marzano (2010) and Winner et al. (2001) worse performance was verified in the majority of the visuospatial skills evaluated in the group with dyslexia; however, in tasks which were more related to the "real world" (computerized tri-dimensional activities made up of the evaluation of the location of paths and constructions) this group had better performance. In addition to this, Eide and Eide (2011) ascertained that individuals with dyslexia, when adults, tend to enter professions which are more linked with visual skills, such as arts, design, architecture and engineering.

Statistically significant differences were not observed between the two groups in the test used for evaluation of intelligence, which was expected in accordance with the diagnostic criteria for dyslexia, which indicates that their difficulties in reading cannot be explained by intellectual deficiency (APA, 2013).

The results showed that, both in the general sample and in the separate analysis of both the groups, there was a strong correlation between the total of the RCPM test and the CFCT $(r=.728$ for the total sample, $r=.737$ for the NG and $r=.801$ for the CG). However, when the effects of age and intelligence were controlled for in the groups, and in the general sample, there was irregularity in the correlations, with both weak and strong correlations being found, significant and not. Through an analysis of the literature, Sternberg (2006) reports having found a series of correlations between measurements of creative performance and conventional intelligence tests, and that the rates were only higher when creativity was related with fluid intelligence, much more so than when related with crystallized intelligence, and even when other variables, such as age, were controlled for.

In assuming the RCPM test to be a measurement related to fluid intelligence, it is possible to verify in the literature studies which found strong correlations with creativity in this type of intelligence, as found in the present study, in making use of the non-case sample (Batey, Chamorro-Premuzic, \& Furnham, 2009; Preckel et al., 2006; Sligh, Conners, \& Roskos-Ewoldsen, 2005). Nevertheless, as was also found here, studies were observed in the literature which indicated weak correlations between creativity and this type of intelligence (Furnham, Batey, Anand, \& Manfield, 2008; Reuter et al., 2005). Thus, it is the case that the irregularity found is also repeated when various similar studies are analyzed.

This instability is also found in the literature, even when other instruments are used for evaluating both the constructs (Nakano, 2012; Nakano \& Brito, 2013; Wechsler et al., 2010). Preckel et al. (2006) state that this diversification of correlations is common, and that it is common for the results to vary depending on how the constructs are measured, and the instrument used, on the theory which they are based on, on the different methodologies, and on the sample studied (which varies depending on age, skill, and educational level), and that for this last reason, investigations on the relationship between creativity and intelligence in specific populations are recommended, such as that undertaken here.

\section{Conclusion}

This study's objectives were investigated, and a certain caution is recommended in interpreting the results, due to the small size of the sample, which requires care to be taken in generalizing the findings. Care should also be taken referent to the definitions of creativity (figurative) and intelligence (fluid) adopted here, under the focus of the psychometric approach. These definitions must be considered only as a statement of the broad field that these concepts can cover. These are complex and multifaceted constructs, as is dyslexia. It is proposed that further studies should include other instruments for evaluating creativity and intelligence, and that other types of creativity (such as verbal) and intelligence (such as crystallized) should be included, as should their relations with other constructs 
already mentioned in the discussion, such as visuospatial processing and emotion, in a wider-reaching form.

Even though better creativity was not found in the group with dyslexia, it is considered that stimulation of this skill could bring benefits for this group, as it promotes the development of learning strategies (Dias, Enumo, \& Azevedo Junior, 2004). Furthermore, it is hoped that this study may be one of the elements driving forward this pattern of investigation, such that creativity, from its evaluation through to its encouragement, may be better investigated, along with other skills which may promote the development of self-esteem and self-confidence in these subjects who, routinely, are judged negatively in the social contacts which occur in the school environment.

\section{References}

Abraham, A., Pieritz, K., Thybusch, K., Rutter, B., Kröger, S., Schweckendiek, J., ... Hermann, C. (2012). Creativity and the brain: Uncovering the neural signature of conceptual expansion. Neuropsychologia, 50(8), 1906-1917. doi:10.1016/j.neuropsychologia.2012.04.015

Alves, R. J. R., \& Nakano, T. C. (In press). Criatividade em indivíduos com transtornos e dificuldades de aprendizagem: Revisão de pesquisas. Psicologia Escolar e Educacional.

American Psychiatric Association. (2013). Diagnostic and statistical manual of mental disorders: DSM-V (5th ed.). Washington, DC: American Psychiatric Association.

Angelini, A. L., Alves, I. C. B., Custódio, E. M., Duarte, W. F., \& Duarte, J. L. M. (1999). Matrizes progressivas coloridas de Raven: Escala especial. Manual. São Paulo, SP: CETEPP.

Barros, D. P., Primi, R., Miguel, F. K., Almeida, L. S., \& Oliveira, E. P. (2010). Metaphor creation: A measure of creativity or intelligence? European Journal of Education and Psychology, 3(1), 103-115.

Batey, M., Chamorro-Premuzic, T., \& Furnham, A. (2009). Intelligence and personality as predictors of divergent thinking: The role of general, fluid and crystallised intelligence. Thinking Skills and Creativity, 4(1), 60-69. doi:10.1016/j.tsc.2009.01.002

Brunswick, N., Martin, G. N., \& Marzano, L. (2010). Visuospatial superiority in developmental dyslexia: Myth or reality? Learning and Individual Differences, 20(5), 421-426. doi:10.1016/j.lindif.2010.04.007

Chakravarty, A. (2009). Artistic talent in dyslexia - A hypothesis. Medical Hypotheses, 73(4), 569-571. doi:10.1016/j.mehy.2009.05.034.

Çorlu, M., Özcan, O., \& Korkmazlar, Ü. (2007). The potential of dyslexic individuals in communication design education. Behavioural Neurology, 18(4), 217-223.

Çorlu, M., Özcan, O., \& Korkmazlar, Ü. (2009). The meaning of dyslexic's drawings in communication design. Dyslexia, 15(2), 147-154. doi:10.1002/dys.362
Dias, T. L., Enumo, S. R. F., \& Azevedo Junior, R. R. (2004). Influências de um programa de criatividade no desempenho cognitivo e acadêmico de alunos com dificuldade de aprendizagem. Psicologia em Estudo, 9(3), 429-437. doi:10.1590/S1413-73722004000300011

Eide, B. L., \& Eide, F. F. (2011). The dyslexic advantage: Unlocking the hidden potential of the dyslexic brain. New York, NY: Hudson Street Press.

Everatt, J., Steffert, B., \& Smythe, I. (1999). An eye for the unusual: Creative thinking in dyslexics. Dyslexia, $\quad 5(1), \quad 28-46 . \quad$ doi:10.1002/(SICI)10990909(199903)5:1<28::AID-DYS126>3.0.CO;2-k

Facoetti, A., Paganoni, P., Turatto, M., Marzola, V., \& Mascetti, G. G. (2000). Visual-spatial attention in developmental dyslexia. Cortex, 6(1), 109-123.

Furnham, A., Batey, M., Anand, K., \& Manfield, J. (2008). Personality, hypomania, intelligence and creativity. Personality and Individual Differences, 44(5), 1060-1069. doi:10.1016/j.paid.2007.10.035

Galaburda, A. M., \& Geschwind, N. (1980). The human language areas and cerebral asymmetries. Revue Médicale de la Suisse Romande, 100(2), 119-128.

Heim, S., Grande, M., Pape-Neumann, J., van Ermingen, M., Meffert, E., Grabowska, A., ... Amunts, K. (2010). Interaction of phonological awareness and 'magnocellular' processing during normal and dyslexic reading: Behavioural and fMRI investigations. Dyslexia, 16(3), 258-282. doi:10.1002/dys.409

Huang, P., Qiu, L., Shen, L., Zhang, Y., Song, Z., Qi, Z., ... Xie, P. (2013). Evidence for a left-over-right inhibitory mechanism during figural creative thinking in healthy nonartists. Human Brain Mapping, 34(10), 2724-2732. doi:10.1002/hbm.22093

Hoppe, K. D. (1988). Hemispheric specialization and creativity. Psychiatric Clinics of North America, 11(3):303-215.

Kim, J.-Y., \& Ko, Y.-G. (2007). If gifted/learning disabled students have wisdom, they haveall things! Roeper Review, 29(4), 249-258. doi:10.1080/02783190709554419

Kim, K. H. (2005). Can only intelligent people be creative? A meta-analysis. Journal of Secondary Gifted Education, 16(2-3), 57-66.

Lockiewicz, M., Bogdanowicz, K. M., \& Bogdanowicz, M. (2013). Psychological resources of adults with developmental dyslexia. Journal of Learning Disabilities. doi: $10.1177 / 0022219413478663$

Nakano, T. C. (2012). Criatividade e inteligência em crianças: Habilidades relacionadas? Psicologia: Teoria e Pesquisa, 28(2), 149-159. doi:10.1590/S0102-37722012000200003

Nakano, T. C., \& Brito, M. E. (2013). Avaliação da criatividade a partir do controle do nível de inteligência em uma amostra de crianças. Temas em Psicologia, 21(1), 1-15. doi:10.9788/TP2013.1-01

Nakano, T. C., Wechsler, S. M., \& Primi, R. (2011). Teste de criatividade figural infantil: Manual técnico. São Paulo, SP: Vetor. 
Nakano, T. C., \& Zaia, P. (2012). Criatividade e inteligência emocional em crianças: Um estudo relacional. Psico, 43(3), 388-399.

Nicolson, R. I., \& Fawcett, A. J. (2011). Dyslexia, dysgraphia, procedural learning and the cerebellum. Cortex, 47(1), 117-127. doi:10.1016/j.cortex.2009.08.016

Pachalska, M., Bogdanowicz, K., Tomaszewska, K., Lockiewicz, M., \& Bogdanowicz, M. (2009). The stimulation of creative activity in dyslexic adults. Acta Neuropsychologica, 7(2), 113-130.

Preckel, F., Holling, H., \& Wiese, M. (2006). Relationship of intelligence and creativity in gifted and nongifted students: An investigation of threshold theory. Personality and Individual Differences, 40(1), 159-170. doi:10.1016/j.paid.2005.06.022

Raven, J. C. (1956). Coloured progressive matrices, Sets A $A B, C$. London: H.K. Lewis \& Co.

Reuter, M., Panksepp, J., Schnabel, N., Kellerhoff, N., Kempel, P., \& Hennig, J. (2005). Personality and biological markers of creativity. European Journal of Personality, 19(2), 83-95. doi:10.1002/per.534

Shaywitz, S. E., \& Shaywitz, B. A. (2008). Paying attention to reading: The neurobiology of reading and dyslexia. Development and Psychopathology, 20(4), 1329-1349. doi:10.1017/S0954579408000631

Sligh, A. C., Conners, F. A., \& Roskos-Ewoldsen, B. (2005). Relation of creativity to fluid and crystallized intelligence. The Journal of Creative Behavior, 39(2), 123-136.

Stein, L. M. (1994). Teste de desempenho escolar. São Paulo, SP: Casa do Psicólogo.

Sternberg, R. J. (2006). Creating a vision of creativity: The first 25 years [Special volume]. Psychology of Esthetics, Creativity, and the Arts, (1), 2-12. doi:10.1037/1931-3896.S.1.2

Tafti, M. A., Hameedy, M. A., \& Baghal, N. M. (2009). Dyslexia, a deficit or a difference: Comparing the creativity and memory skills of dyslexic and nondyslexic students in Iran. Social Behavior and Personality, 37(8), 1009-1016. doi:10.2224/sbp.2009.37.8.1009

Torrance, E. P. (1965). Rewarding creative behavior: Experiments in classroom creativity. Englewood Cliffs, NJ: Prentice Hall.

Torrance, E. P., \& Safter, H. T. (1999). Making the creative leap beyond. Buffalo, NY: Creative Education Foundation.

Wechsler, S. M., Nunes, M. F. O., Schelini, P. W., Ferreira, A. A., \& Pereira, D. A. P. (2010). Criatividade e inteligência: Analisando semelhanças e discrepâncias no desenvolvimento. Estudos de Psicologia (Natal), 15(3), 243-250. doi:10.1590/S1413-294X2010000300003

West, T. G. (2009). In the mind's eye: Creative visual thinkers, gifted dyslexics, and the rise of visual technologies (2nd ed.). New York, NY: Prometheus Books.

Winner, E., von Karolyi, C., Malinsky, D., French, L., Seliger, C., Ross, E., \& Weber, C. (2001). Dyslexia and visualspatial talents: Compensation vs deficit model. Brain and Language, 76(2), 81-110. doi:10.1006/brln.2000.2392
World Health Organization (2008). The ICD-10 classification of mental and behavioural disorders description and diagnostic guidelines. Geneva: World Health Organization.

Rauni Jandé Roama Alves is a Ph.D. candidate of the Graduate Program in Psychology at the Pontifícia Universidade Católica de Campinas.

Tatiana de Cássia Nakano is a Full Professor of the Graduate Program in Psychology at the Pontifícia Universidade Católica de Campinas.

Received: Mar. 19, 2014

1st Revision: June 12, 2014

2nd Revision: July 15, 2014

Approved: July 25, 2014
How to cite this article:

Alves, R. J. R., \& Nakano, T. C. (2014). Creativity and intelligence in children with and without developmental dyslexia. Paidéia (Ribeirão Preto), 24(59), 361-369. doi: 10.1590/1982-43272459201410 


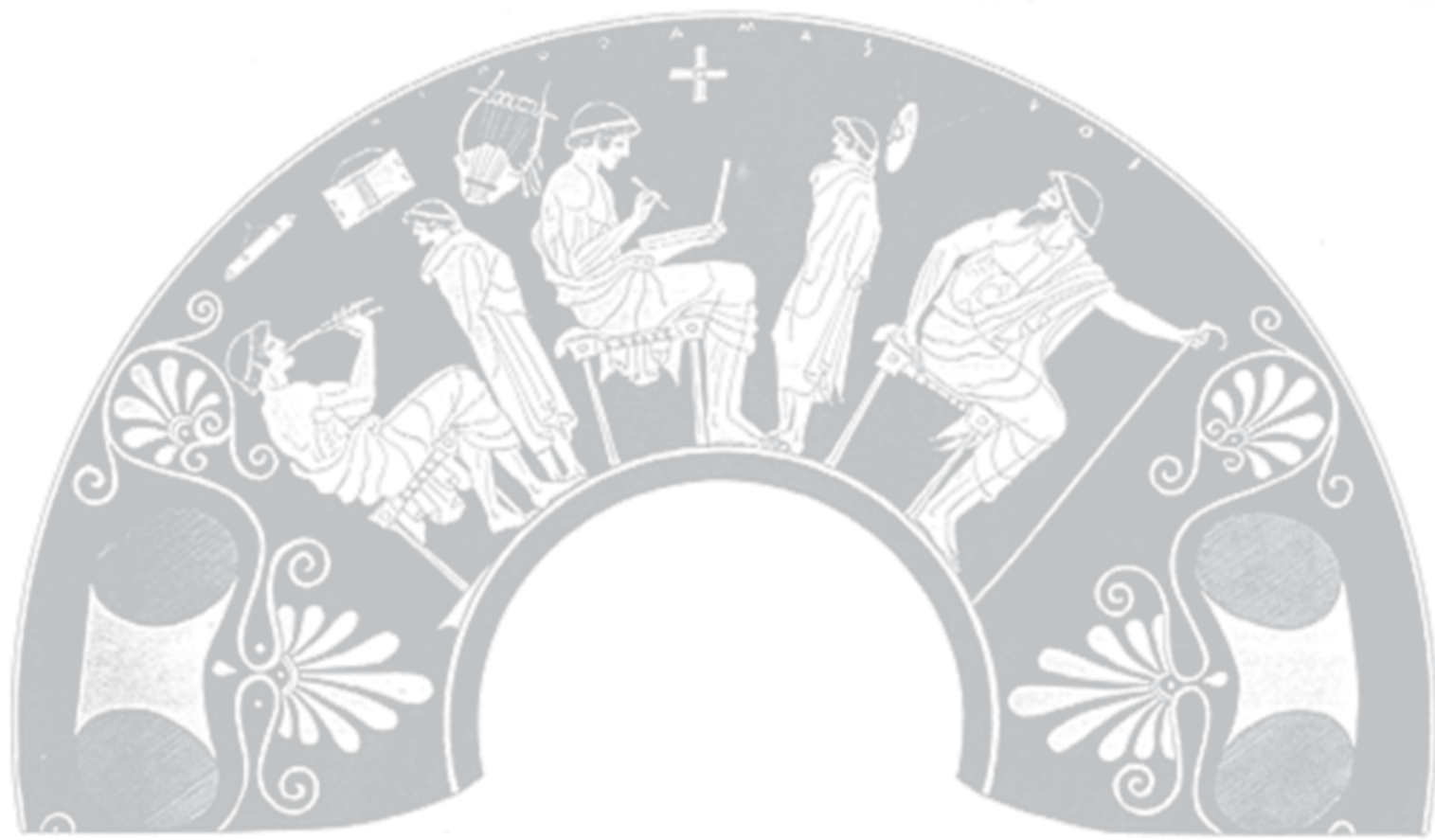

